PERFECT ME 



\section{Perfect Me}

\section{Beauty as an \\ Ethicalldeal}

Heather Widdows

PRINCETON UNIVERSITY PRESS

PRINCETON AND OXFORD 
Copyright $\odot 2018$ by Princeton University Press

Published by Princeton University Press,

41 William Street, Princeton, New Jersey 08540

In the United Kingdom: Princeton University Press, 6 Oxford Street, Woodstock, Oxfordshire OX20 1TR

press.princeton.edu

All Rights Reserved

ISBN 978-0-691-16007-8

Library of Congress Control Number: 2017956005

British Library Cataloging-in-Publication Data is available

Editorial: Al Bertrand and Kristin Zodrow

Production Editorial: Debbie Tegarden

Jacket Design: Faceout Studio, Charles Brock

Jacket image courtesy of Liliya Rodnikova / Stocksy

Production: Jacquie Poirier

Publicity: Jodi Price

Copyeditor: Jay Boggis

This book has been composed in Adobe Text Pro and Gotham

Printed on acid-free paper. $\infty$

Printed in the United States of America

$\begin{array}{llllllllll}10 & 9 & 8 & 7 & 6 & 5 & 4 & 3 & 2 & 1\end{array}$ 
For Clara, my piece of perfect. 
